\title{
Assessment of Cardiovascular Disease Risk in South Asian Populations
}

\author{
S. Monira Hussain, Brian Oldenburg, Yuanyuan Wang, \\ Sophia Zoungas, and Andrew M. Tonkin \\ Department of Epidemiology and Preventive Medicine, Monash University, The Alfred Centre, Melbourne, VIC 3004, Australia \\ Correspondence should be addressed to Andrew M. Tonkin; andrew.tonkin@monash.edu
}

Received 27 June 2013; Accepted 14 August 2013

Academic Editor: Karlheinz Peter

Copyright (c) 2013 S. Monira Hussain et al. This is an open access article distributed under the Creative Commons Attribution License, which permits unrestricted use, distribution, and reproduction in any medium, provided the original work is properly cited.

Although South Asian populations have high cardiovascular disease (CVD) burden in the world, their patterns of individual CVD risk factors have not been fully studied. None of the available algorithms/scores to assess CVD risk have originated from these populations. To explore the relevance of CVD risk scores for these populations, literature search and qualitative synthesis of available evidence were performed. South Asians usually have higher levels of both "classical" and nontraditional CVD risk factors and experience these at a younger age. There are marked variations in risk profiles between South Asian populations. More than 100 risk algorithms are currently available, with varying risk factors. However, no available algorithm has included all important risk factors that underlie CVD in these populations. The future challenge is either to appropriately calibrate current risk algorithms or ideally to develop new risk algorithms that include variables that provide an accurate estimate of CVD risk.

\section{Introduction}

Cardiovascular diseases (CVD) related to atherosclerosis, including ischaemic heart disease, stroke, and peripheral vascular disease, are the leading causes of death in most of high-, low-, and middle-income countries [1]. Although low- and middle-income countries account for more than $80 \%$ of global deaths and $85 \%$ of global disability from CVD, with a few notable exceptions, knowledge and understanding of CVD risk factors are largely derived from data obtained in developed countries [2].

Atherosclerosis and its complications develop over the entire life course as a result of combined influences of lifestyle-related factors, environmental triggers, and genetic susceptibility [3]. Clinically overt CVD is usually preceded by the presence of one or more risk factors and subclinical atherosclerosis [3], and the relationship between risk factors and CVD outcomes represents a continuum. As the individual risk varies greatly, methods that estimate the risk of future CVD events have been developed and applied. Such algorithms recognise the continuous relationship between levels of biomedical and lifestyle variables and future CVD events, weigh risk factors according to their importance, and allow for potential synergistic effects of abnormalities in individual risk factors. Such scores not only stratify individual risk and identify those most likely to benefit from an intervention, but also inform the most cost-effective allocation of preventive therapies.

A risk scoring method should include appropriate risk factors, be accurate, and be ideally validated in the population in which it is applied. Importantly, it might be also favourably influencing clinical behaviour. We anticipated that risk estimation methods widely used in low- and middleincome countries albeit sometimes calibrated using local risk factor prevalence and disease incidence data might have been developed from studies of populations based in high-income countries [2]. However to our knowledge, such calibration had not been undertaken in South Asian populations, which include Afghanistan, Bangladesh, Bhutan, India, Maldives, Nepal, Pakistan, and Sri Lanka, which are estimated to contain more than 1.64 billion people, in excess of $24 \%$ of the world's current population [4].

This paper examines the implications of CVD risk algorithms because of the potential limitations in current CVD 


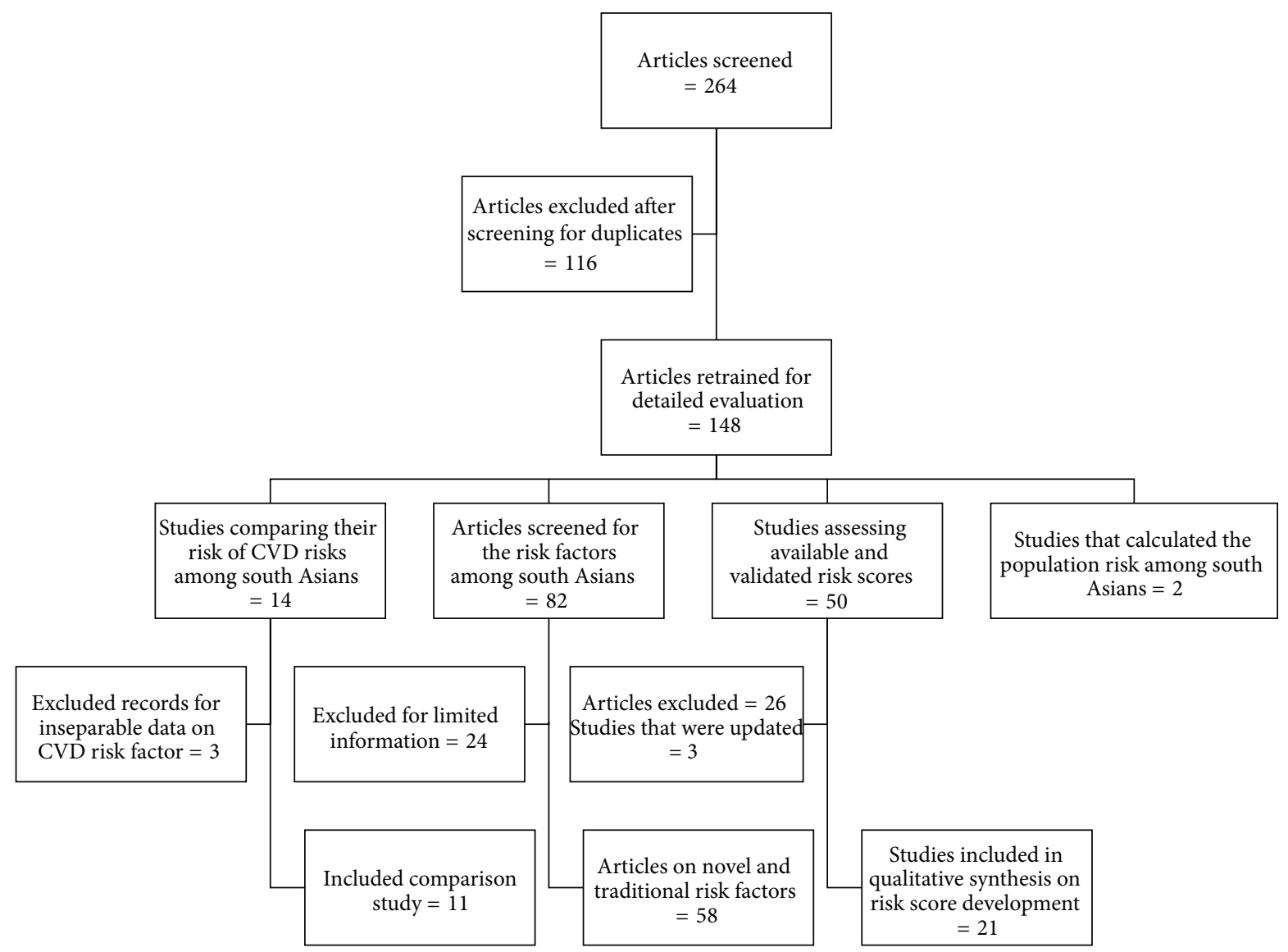

FIGURE 1: Flow diagram for the included articles.

risk assessment approaches for prevention and control of atherosclerotic CVD in South Asian populations.

\section{Methods}

MEDLINE, Google scholar, and Embase were searched using the MeSH terms and free texts for the key words, such as "cardiovascular", "coronary", "heart disease", "risk equation", "risk algorithm", "risk predictions", "risk scores”, "risk engines", "risk assessments", "risk factors", and "South Asians", from 1970 until July 2012. To identify other studies which also addressed the above questions, relevant book chapters and other manuscripts were also examined after citation tracking.

A study was eligible for review if it fulfilled any of the following criteria: (1) if it compared CVD risk profiles between South Asians and Caucasians or between South Asians in their home country and South Asians living abroad; (2) if it assessed CVD risk factors that are prevalent among South Asians; (3) if it formed at least part of the evidence base for the development of a CVD risk score/equation; (4) if it examined the use of CVD risk tool(s) in South Asians.

Details concerning inclusion and exclusion of studies are outlined in Figure 1. Two reviewers ( $\mathrm{SMH}$ and $\mathrm{YW}$ ) extracted information concerning study demographics, the predictive variables examined, and clinical end-points for each study.

\section{Results}

3.1. CVD Risk Profiles in South Asians Compared with Those in Caucasians and South Asians Living in Other Countries. The diversity and differences in CVD risk factors in native South Asians compared to South Asians who have migrated abroad and between the South Asians and other ethnic groups (Caucasians and Chinese) are shown in Table 1. There were marked differences in the distribution of CVD risk factors [57]. It was concluded that the wide array of differences in CVD risk profile makes combining data from different misleading South Asian countries [6, 7]. Even within countries such as India, marked variations in risk profiles due to difference in culture, lifestyle, and religion have been reported. Nevertheless, all of these studies have concluded that despite their lower body mass index (BMI), body weight, and serum cholesterol, South Asians have greater evidence of other features of dyslipidaemia including lipoprotein(a) and other CVD risk factors than Caucasians [5-10]. Additionally, South Asians had more prominent abnormalities in fibrinogen, plasminogen activator inhibitor 1, homocysteine, C-reactive protein, insulin sensitivity, and psychosocial factors (stress, depression) [6-9].

3.2. Assessment of CVD Risk Factors in South Asians in Their Native Countries. The widely discussed CVD risk factors 
TABLE 1: Variations of risk factors in South Asians in their home countries or migrant South Asians compared with the other populations.

\begin{tabular}{|c|c|c|c|c|}
\hline Author \& year & Study design & Study population & Risk factors estimated & Conclusion \\
\hline $\begin{array}{l}\text { Bhatnagar } \\
\text { et al. [11] } 1995\end{array}$ & Cross-sectional & $\begin{array}{l}\text { Total } 364 \\
\text { British Punjab 247, } \\
\text { Indian Punjab } 117\end{array}$ & $\begin{array}{l}\text { BMI, BP, TC, TG, HDL, } \\
\text { apo B, Lp(a), insulin } \\
\text { sensitivity, } \beta \text { cell function, } \\
\text { blood glucose }\end{array}$ & $\begin{array}{l}\text { (i) Indian migrants in the UK have a less } \\
\text { favourable coronary risk profile } \\
\text { (ii) Indians have higher serum Lp(a) which is } \\
\text { not affected by migration } \\
\text { (iii) Deterioration of insulin resistance and } \beta \\
\text { cell function is associated with migration }\end{array}$ \\
\hline
\end{tabular}

(i) South Asians have a higher prevalence of

Total 1578

British white 524,

Cappuccio Cross-sectional British African 549,

et al. [5] 1997 British South Asian 505
BP, diabetes, BMI, serum cholesterol, smoking hypertension and diabetes than Caucasians (ii) One in five people of South Asian origin had diabetes

(iii) CHD is the first cause of death among South Asians

(iv) There are marked differences in the distribution of CVD risk factors among Caucasians, South Asians and Africans

(i) South Asians have more CHD than

Total 1508 684 South Asians (British Indian 259,

Bhopal et al. [6] 1999

Cross-sectional

British Pakistani 305, 120), British Europeans 825 British Bangladeshi
TC, HDL, LDL, TG, Lp(a) lipoprotein, fibrinogen, insulin, and glucose, Height, weight, waist and hip, BP, ECG, smoking, diet, alcohol consumption, exercise
Europeans despite apparently lower levels of risk factors

(ii) Indians, Pakistanis and Bangladeshis differ in a wide range of coronary risk factors

(iii) Among South Asians, Indians were least and Bangladeshis were most disadvantaged in a range of coronary risk factors

(iv) Combining the data on CVD risk factors from Indians, Pakistanis and Bangladeshis is misleading

(i) Asians had more plasma lipid and glucose

BP, BMI, waist : hip ratio,
Total 985

Anand et al. [8] 2000

Cross-sectional

South Asians 342,

European 326,

Chinese 317
LVH, TC, LDL, HDL, TG,

blood glucose, Lp(a), homocysteine, PAI-1, fibrinogen, smoking, subclinical atherosclerosis abnormalities

(ii) South Asians had the highest prevalence of CVD and highest DBP

(iii) South Asians had greater abnormalities in novel risk factors: fibrinogen, PAI-1, Lp(a) and homocysteine

(i) CRP levels are elevated in Indian Asians and are associated with an increase in population CHD risk among Indian Asian

(ii) Diabetes, insulin resistance and related metabolic abnormalities are more common among Indian Asians

(iii) CRP levels were more closely associated with increased central adiposity and markers of insulin resistance
Chambers et al. [9] 2001

Cross-sectional Indian Asians 518, European whites 507
Age, CRP, BMI, Waist : hip ratio, $\mathrm{BP}$, smoking, physical activity, blood glucose, TC, HDL, TG, insulin resistance
Mahajan and Bermingham [14] 2004
Total 250 Australian Indians 125 , Indian Indians 125
Age, BMI, Waist, Waist : hip

ratio, Smoking, alcohol consumption, food habit, exercise, TC, HDL, TG, LDL, Apo A1, Apo B, Lp(a), Insulin
Age, education, smoking, alcohol intake, height, BMI, Waist : hip ratio, ECG, BP, blood glucose, physical activity, energy intake, folate, vit B12, energy from fat \& carbohydrate, TC, TG, NEFA, HDL, LDL, Apo B, Apo AI, Apo B : AI ratio, Lp(a), CRP, Homocystine, Serum folate \& vit B12, Plasma insulin, HOMA B, HOMA S (i) Migration adversely influences some of the CVD risk factors, like-apo B, plasma insulin, CRP

(ii) Migration makes British Gujaratis more prone to CVD than Indian Gujaratis
Patel et al.
[49] 2006 Cross-sectional (i) Indians migrated to Australia have a more favourable CHD risk factor profile than the Indians remaining in India

(ii) It is unlikely that changes due to migration have a strong genetic bias
British Gujarati 242,

Indian Gujarati 294 
TABle 1: Continued.

\begin{tabular}{|c|c|c|c|c|}
\hline Author \& year & Study design & Study population & Risk factors estimated & Conclusion \\
\hline $\begin{array}{l}\text { Joshi et al. } \\
\text { [7] } 2007\end{array}$ & Case-control & $\begin{array}{l}\text { Total } 29,972 \\
(\text { Case }+ \text { control) } \\
\text { India } 470+940, \\
\text { Pakistan } 637+655, \\
\text { Sri Lanka } 153+132, \\
\text { Bangladesh } 228+238, \\
\text { Nepal } 244+239 \\
\text { Other countries } \\
13420+12616\end{array}$ & $\begin{array}{l}\text { Age, SES, tobacco use, } \\
\text { alcohol, physical activity, } \\
\text { dietary patterns, personal or } \\
\text { family history of CVD, } \\
\text { hypertension, stress and } \\
\text { depression, Height, weight, } \\
\text { waist : hip ratio, apo B100 and } \\
\text { apoA-I, ApoB100: ApoA-I } \\
\text { ratio, diabetes }\end{array}$ & $\begin{array}{l}\text { (i) Participants of South Asian countries } \\
\text { experience fatal CHD at younger ages } \\
\text { (ii) Variations in the mean age of presentation } \\
\text { of cases were observed between countries } \\
\text { within South Asia } \\
\text { (iii) Bangladeshis had the highest prevalence } \\
\text { for the most of the CVD risk factors among } \\
\text { controls } \\
\text { (iv) Indians have the higher prevalence of } \\
\text { diabetes }\end{array}$ \\
\hline $\begin{array}{l}\text { Tennakoon } \\
\text { et al. [50] } 2010\end{array}$ & Cross-sectional & $\begin{array}{l}\text { Total } 1378 \\
\text { Norwegian Sri } \\
\text { Lankans 1145, Sri } \\
\text { Lankans in Sri Lanka } \\
233\end{array}$ & $\begin{array}{l}\text { Age, education, smoking, } \\
\text { TC, HDL, TC: HDL ratio, } \\
\text { TG, Height, BMI, Waist } \\
\text { circumference, BP }\end{array}$ & $\begin{array}{l}\text { (i) Norwegian Sri Lankans have favourable } \\
\text { lipid profiles and blood pressure levels despite } \\
\text { being more obese compared with people living } \\
\text { in Sri Lanka } \\
\text { (ii) Educated persons in Sri Lanka are in more } \\
\text { risk of having higher triglyceride, obesity, and } \\
\text { blood pressure compared to the uneducated } \\
\text { people }\end{array}$ \\
\hline $\begin{array}{l}\text { Chiu et al. } \\
\text { [10] } 2010\end{array}$ & Cross-sectional & $\begin{array}{l}\text { Total 163,797 } \\
\text { Canadian White } \\
\text { 154653, Canadian } \\
\text { South Asians 3364, } \\
\text { Canadian Chinese } \\
\text { Total 3038, } \\
\text { Canadian black } \\
\text { people } 2742 \\
\end{array}$ & $\begin{array}{l}\text { Age, education, sex, current } \\
\text { smoking, obesity, Diabetes, } \\
\text { BP, stress, consumption of } \\
\text { fruits and vegetables, physical } \\
\text { activity, non-regular alcohol } \\
\text { consumption }\end{array}$ & $\begin{array}{l}\text { (i) There are differences in the prevalence of } \\
\text { CVD risk factors across ethnic groups } \\
\text { (ii) Canadian South Asians are less obese than } \\
\text { whites, but they suffers more from diabetes and } \\
\text { hypertension } \\
\text { (iii) The protective factors like fruit and } \\
\text { vegetable consumption, exercising habit, are } \\
\text { less common in Canadian South Asians }\end{array}$ \\
\hline $\begin{array}{l}\text { Zahid et al. } \\
\text { [51] } 2011\end{array}$ & Cross-sectional & $\begin{array}{l}\text { Total } 2000 \\
\text { Norwegian Pakistani } \\
770 \text {, Pakistanis living } \\
\text { in Pakistan } 1230\end{array}$ & $\begin{array}{l}\text { Age, height, weight, BMI, } \\
\text { Waist circumference, Hip } \\
\text { circumference, Waist: hip } \\
\text { ratio, smoking, TC, HDL, BP }\end{array}$ & $\begin{array}{l}\text { (i) Obesity and CVD risk factors are widely } \\
\text { prevalent in both Norwegian Pakistani and } \\
\text { Pakistanis living in Pakistan } \\
\text { (ii) Migration makes Norwegian Pakistani } \\
\text { more likely to have CVD risk factors (obesity } \\
\text { and dyslipidemia) compared to Pakistanis at } \\
\text { their homeland }\end{array}$ \\
\hline
\end{tabular}

BMI: Body mass index, BP: Blood pressure, TC: Total cholesterol, HDL: High density lipoprotein, LDL: Low density lipoprotein, TG: Triglyceride, apo: Apolipoprotein, Lp: lipoprotein, ECG: Echo cardiogram, LVH: Left ventricular hypertrophy, PAI: Plasminogen activator inhibitor, CRP: C reactive protein, vit: Vitamin, NEFA: Nonesterified fatty acids, HOMA: homeostatic model assessment.

in South Asians are listed in Table 2. The INTERHEART study and other recent researches in Singapore, the United Kingdom, and Canada, which examined large populations from South Asian countries $[7,8,10,11]$, reported that South Asians tended to experience both the "classical" and nontraditional CVD risk factors in a higher level and at a younger age than the other populations $[7,8,11,12]$. For example, South Asians were more likely to have more severe abnormalities of harmful factors-including elevated apo B100/apo A-I ratio [7, 11, 13], lipoprotein(a) [8, 11, 14], depression, and stress at work or home [7,13], and had lower rates of protective factors-physical activity $[7,13]$, regular fruits, and vegetable intake $[7,13]$. Concurrently, potentially widespread environmental pollution, such as that from arsenic contamination and indoor air pollution, further complicates the situation. Arsenic exposure which is associated with vascular inflammation and endothelial dysfunction exerted by atherosclerotic plaque, oxidative stress, and lipid peroxidation [15] is a huge problem for an estimated 40-60 million people in the Ganges delta of South Asia [16] as they consume arsenic contaminated groundwater [16] and food from plant origin [17]. Most of the rural houses in Bangladesh [18] and 75\% of households of India [19] use solid fuels for cooking which are the major sources of indoor air pollution and pose serious health risks including CVD and low birth weight $[18,19]$.

With $31 \%$ of all infants born with low birth weight, South Asians had the highest incidence of this problem [20] which has been consistently associated with increased risk of insulin resistance and atherosclerotic CVD later in life [21, 22]. It has been postulated that low birth weight contributes to the early development of the CVD risk factors, including blood pressure and plasma glucose concentrations, insulin resistance, abnormal fibrinogen/factor VII, and apolipoprotein levels [23] that are common among South Asians.

3.3. Currently Available and Validated Risk Algorithms. Table 3 summarizes details concerning the most widely used risk scores, the populations from which they were derived, the risk factors included, and the different CVD outcomes which were 
TABLE 2: Widely distributed cardiovascular disease risk factors among South Asians.

Traditional risk factors Nontraditional risk factors Nonmodifiable

(i) Low birth weight $[21,22,55]$

(ii) Abnormal foetal growth [21, 22] Modifiable

(i) Insulin resistance $[6,9,11,14,49,56]$

Nonmodifiable

(i) Age

(ii) High apo B100/apo A-I ratio

(ii) Sex

(iii) Familial

Modifiable

$[7,11,13,14]$

(iii) Low adiponectin [8]

(iv) Lipoprotein (a) $[6,8,11,14]$

(v) Homocysteine $[8,49]$

(i) High blood pressure (vi) Apolipoprotein B [7, 11, 14, 49]

(ii) Diabetes

(iii) Dyslipidaemia

(iv) Abdominal obesity

(v) Smoking

(vii) Visceral and ectopic fat [13]

(viii) Plasminogen activator inhibitor-1 [8]

(ix) Fibrinogen [8]

(x) Endothelial dysfunction

(xi) Low physical activity $[6,7,10,14,49]$

(xii) Dietary habit $[7,10,13]$

(xiii) Alcohol consumption $[6,7,10,13]$

(xiv) Psychosocial factors $[7,10,13]$

examined. A person's estimated probability of developing a major CVD event(s) during the following 5-or 10-year period is known as absolute or short-term risk. Absolute risk calculators are developed and validated in longitudinal cohort studies which estimate the effect of multiple CVD risk factors on CVD events [24]. However, if any CVD risk factor was left untreated for a long time, it can produce high risk and cumulative damage [25]. Not only for this reason but also because age is the major determinant of shortterm absolute risk a lifetime risk, scoring method has been developed and has been recommended for younger patients to offer additional risk burden.

The relationship between independent major risk factors and coronary heart disease (CHD) risk was first described over 50 years ago using data from the Framingham Heart study. Since then, over 100 different CVD risk scores have been developed, mainly based on findings on Caucasians in developed countries. Among the most commonly used risk scores, at least five have been derived from the Framingham study [26-28]. Other studies from which risk scores have been derived include those of the Munster group (PROCAM) [29], ARIC [30], QRISK (electronic medical database) [31, 32], Reynolds [33, 34], the Scottish Heart Health Extended Cohort [35], Strong Heart Study [36], USA-PRC (People's Republic of China Collaborative Study of Cardiovascular Epidemiology) [37], the SCORE project [38], Personal heart [39], NHEFS [2], and the UKPDS [40]. None of the above risk scores have been derived from epidemiologic studies undertaken in developing countries and/or a South Asian population living in South Asia. Although the IHMRS (obtained from INTERHEART data) has been validated in South Asians, it has the limitation of being derived from a case-control study which might not be considered to be as robust in predicting future events as equations derived from prospective data [41].
The numbers of risk factors that incorporated into the risk scores have varied widely ranging from 4 to 14 . All algorithms have included age, gender, blood pressure, and smoking status, and also they almost included lipid parameter(s) and diabetes status. Of note, lipid parameters were not included in the nonlaboratory model of the 2008 Framingham risk score [28], the PROCAM 2007 (stroke) risk score [29] or the NHEFS risk score [2]. The CVD outcome(s) predicted by the risk scores also differs markedly, as again shown in Table 3.

3.4. Calculation of CVD Risk with Currently Available Risk Tools. There is no specific risk score that has been derived from South Asian populations; nor to our knowledge has any attempt been made to calibrate either short-term or lifetime risk stratification algorithms in these populations.

Some of the currently available risk scores have been applied to calculate CVD risk in South Asians. For example, when the ATP III (Adult Treatment Panel) risk score (based on the Framingham study) was applied to a cohort of healthy Indian industrial workers of $40.8 \pm 10.9$ years of age on average (range 20-69 years), it was estimated that one in two men and three in four women had a low short-term risk for CVD [42]. Based on this aggregate of risk factor burden, these results highlight a key limitation-an overestimation of CVD risk [42]. As with almost all of the combinations of risk factors at their extreme values, the ATP III risk score predicts 10 -year CVD risks below $10 \%$ for nonsmoking men $<45$ years of age and all women $<65$ years of age [43]. In another Indian cohort, three risk scores were applied and predicted different levels of CVD risk for the individuals in the same population [12]. The Framingham model predicted only $5.3 \%$ of the study subjects (males aged $37.2 \pm 14$ years and females aged $43.2 \pm 13.7$ years) at high risk; an apparent underestimation [12] has given that an adjusted Framingham score calculates 30 -year risks to be $7.9 \%$ for women and $18.0 \%$ for men in the population from which it originated [44]. That Framingham algorithm has been observed to perform poorly across socioeconomic groups, and underestimated risk in socioeconomically deprived groups [45] may be an explanation for this underestimation. The Joint British Cardiac Society (BCS)/British Hypertension Society (BHS)/British Hyperlipidemia Association (BHA) risk score also appeared to underestimate the CVD risk [12]. However, the risk underestimation by the Framingham algorithm and the British Cardiac Society algorithm was disproportionate (5.3\% by Framingham, 3.7\% and $4.4 \%$ by the joint British Societies scores, resp.) [12].

\section{Discussion}

This review has shown that the distribution of CVD risk factors varies markedly in South Asians. Along with the conventional CVD risk factors, some influential nontraditional risk factors which are more common among these populations may be relevant in explaining why South Asians have CVD risk in a higher level and at a younger age. Studies have found that the predictability of CVD risk scores, which were developed mainly for Caucasians, varies considerably mainly 
TABLE 3: Key characteristics of important cardiovascular risk algorithms.

\begin{tabular}{|c|c|c|c|c|}
\hline Risk scores & Country & Population & Risk factors & Outcomes \\
\hline $\begin{array}{l}\text { Framingham } \\
\text { [26] } 1976\end{array}$ & USA & Population cohort & $\begin{array}{l}\text { Age, sex, smoking, SBP, total cholesterol, } \\
\text { random blood sugar and urinary blood } \\
\text { glucose, ECG-LVH }\end{array}$ & $\begin{array}{l}\text { Deaths from CHD and other fatal CVD, } \\
\text { MI, ischaemic stroke, haemorrhagic } \\
\text { stroke, angina pectoris, PAD, } \\
\text { hypertensive CCF }\end{array}$ \\
\hline $\begin{array}{l}\text { Framingham } \\
\text { [27] } 1991\end{array}$ & USA & $\begin{array}{l}\text { Population cohort } \\
\text { (original }+ \\
\text { offspring) }\end{array}$ & $\begin{array}{l}\text { Age, sex, smoking, SBP, DBP, TC, HDL, } \\
\text { RBS, (offspring FBS) ECG-LVH }\end{array}$ & Death from $\mathrm{CHD}, \mathrm{MI}$, angina pectoris \\
\hline $\begin{array}{l}\text { Framingham } \\
\text { [57] } 1998\end{array}$ & USA & $\begin{array}{l}\text { Population cohort } \\
\text { (original }+ \\
\text { offspring) }\end{array}$ & $\begin{array}{l}\text { Age, sex, smoking, SBP, DBP, TC or LDL, } \\
\text { RBS, (offspring FBS) }\end{array}$ & Death from $\mathrm{CHD}, \mathrm{MI}$, angina pectoris \\
\hline $\begin{array}{l}\text { Framingham } \\
\text { [28] } 2008\end{array}$ & USA & $\begin{array}{l}\text { Population cohort } \\
\text { (original }+ \\
\text { offspring) }\end{array}$ & $\begin{array}{l}\text { Lab based-Age, sex, smoking, SBP, TC, } \\
\text { HDL, FBS, antihypertensive } \\
\text { Non-lab-Age, sex, smoking, SBP, FBS, } \\
\text { antihypertensive, BMI }\end{array}$ & $\begin{array}{l}\text { Deaths from CHD and other fatal CVD, } \\
\text { MI, ischaemic stroke, haemorrhagic } \\
\text { stroke, TIA, angina pectoris, PAD, } \\
\text { hypertensive CCF }\end{array}$ \\
\hline $\begin{array}{l}\text { UKPDS [40] } \\
2001\end{array}$ & $\begin{array}{l}\text { UK diabetes } \\
\text { prevention } \\
\text { trial }\end{array}$ & Population cohort & $\begin{array}{l}\text { Age at diagnosis of diabetes, smoking, } \\
\text { SBP, TC/HDL, } \mathrm{HbA}_{1 \mathrm{c}} \text {, ethnicity }\end{array}$ & Hard CHD \\
\hline $\begin{array}{l}\text { PROCAM [29] } \\
2007\end{array}$ & Germany & $\begin{array}{l}\text { Occupational } \\
\text { cohort }\end{array}$ & $\begin{array}{l}\text { CHD-Age, sex, smoking, SBP, LDL, HDL, } \\
\text { TG, FBS, family history } \\
\text { Stroke-Age, sex, smoking, SBP, FBS }\end{array}$ & $\begin{array}{l}\text { Deaths from } \mathrm{CHD} \text { and } \mathrm{MI} \\
\text { Ischemic stroke, TIA }\end{array}$ \\
\hline $\begin{array}{l}\text { SCORE [38] } \\
2003\end{array}$ & Europe & $\begin{array}{l}\text { Pooled dataset of } \\
\text { cohort studies }\end{array}$ & Age, sex, smoking, BP, TC or TC: HDL & $\begin{array}{l}\text { Deaths from CHD and other fatal CVD, } \\
\text { fatal MI, fatal ischemic score, fatal PAD, } \\
\text { fatal hypertensive CCF }\end{array}$ \\
\hline ARIC [30] 2003 & USA & Population cohort & $\begin{array}{l}\text { moking, SBP, TC, HDL, FBS, } \\
\text { ensive, ethnicity }\end{array}$ & $\begin{array}{l}\text { Death form CHD, MI, revascularisation } \\
\text { intervention }\end{array}$ \\
\hline $\begin{array}{l}\text { Dubbo equation } \\
\text { [58] } 2003\end{array}$ & Australia & $\begin{array}{l}\text { Second Australian } \\
\text { national blood } \\
\text { pressure study }\end{array}$ & $\begin{array}{l}\text { Age, sex, smoking, SBP, antihypertensive } \\
\text { medication, TC, HDL, diabetes }\end{array}$ & CVD \\
\hline $\begin{array}{l}\text { Progetto } \\
\text { coure [59] } 2004\end{array}$ & Italy & $\begin{array}{l}\text { Pooled dataset of } \\
\text { cohort studies }\end{array}$ & $\begin{array}{l}\text { Age, sex, smoking, SBP, TC, HDL, FBS, } \\
\text { antihypertensive }\end{array}$ & $\begin{array}{l}\text { Deaths from CHD and other fatal CVD, } \\
\text { MI, ischemic stroke, haemorrhagic } \\
\text { stroke, revascularisation intervention }\end{array}$ \\
\hline $\begin{array}{l}\text { DECODE [60] } \\
2005\end{array}$ & Sweden & $\begin{array}{l}\text { National diabetes } \\
\text { registry }\end{array}$ & $\begin{array}{l}\text { Age, state of glucose tolerance, FBS, } \\
\text { smoking, SBP, TC, HDL, BMI, HR }\end{array}$ & Fatal CVD and first incident CVD \\
\hline $\begin{array}{l}\text { Riskard [61] } \\
2005\end{array}$ & Italy & Population cohort & $\begin{array}{l}\text { Age, sex, smoking, mean BP, HDL-C, } \\
\text { non-HDL-C, diabetes, BMI, heart rate }\end{array}$ & CVD, CHD and stroke \\
\hline $\begin{array}{l}\text { Zhang et al. } \\
\text { [62] } 2005\end{array}$ & China & $\begin{array}{l}\text { Occupational } \\
\text { cohort }\end{array}$ & $\begin{array}{l}\text { CHD-Age, smoking, SBP, TC, BMI } \\
\text { Ischemic stroke-age, smoking, SBP, TC } \\
\text { Haemorrhagic stroke-age, SBP, DBP, TC }\end{array}$ & $\begin{array}{l}\text { CHD } \\
\text { Ischaemic stroke } \\
\text { Haemorrhagic stroke }\end{array}$ \\
\hline $\begin{array}{l}\text { Strong Heart } \\
\text { Study [36] } 2006\end{array}$ & USA & $\begin{array}{l}\text { Population } \\
\text { cohort-American } \\
\text { Indian }\end{array}$ & $\begin{array}{l}\text { Age, sex, smoking, SBP, TC or LDL, HDL, } \\
\text { FBS, antihypertensive, albuminuria }\end{array}$ & $\begin{array}{l}\text { Death from } \mathrm{CHD}, \mathrm{MI} \text {, angina pectoris, } \\
\text { revascularisation interventions }\end{array}$ \\
\hline $\begin{array}{l}\text { USA-PRC [37] } \\
2006\end{array}$ & China & Population cohort & Age, sex, smoking, SBP, TC, FBS, BMI & $\begin{array}{l}\text { Deaths from CHD and other fatal CVD, } \\
\text { MI, ischemic stroke }\end{array}$ \\
\hline $\begin{array}{l}\text { NIPPON data80 } \\
\text { [63] } 2006 \\
\end{array}$ & Japan & Population cohort & $\begin{array}{l}\text { Age, sex, smoking, SBP, TC, blood } \\
\text { glucose }\end{array}$ & Fatal CHD, fatal stroke, and fatal CVD \\
\hline $\begin{array}{l}\text { ASSIGN [35] } \\
2007\end{array}$ & UK & Population cohort & $\begin{array}{l}\text { Age, sex, smoking, SBP, TC, HDL, } \\
\text { diabetes, family history, socioeconomic } \\
\text { status }\end{array}$ & $\begin{array}{l}\text { Deaths from CHD and other fatal CVD, } \\
\text { MI, revascularisation intervention, } \\
\text { hypertensive CCF and; admitted for MI, } \\
\text { ischemic stroke, haemorrhagic stroke, } \\
\text { TIA or angina pectoris }\end{array}$ \\
\hline $\begin{array}{l}\text { Reynolds } \\
\text { women [33] } 2007\end{array}$ & USA & $\begin{array}{l}\text { Women's health } \\
\text { Study trial subjects }\end{array}$ & $\begin{array}{l}\text { Age, smoking, self-reported BP, TC, } \\
\mathrm{HDL}, \mathrm{HbA}_{\mathrm{lc}} \text { (if diabetic), family history, } \\
\text { hs-CRP }\end{array}$ & $\begin{array}{l}\text { Deaths from CHD and other fatal CVD, } \\
\text { MI, ischaemic stroke, revascularisation } \\
\text { intervention }\end{array}$ \\
\hline
\end{tabular}


TABLE 3: Continued.

\begin{tabular}{|c|c|c|c|c|}
\hline Risk scores & Country & Population & Risk factors & Outcomes \\
\hline $\begin{array}{l}\text { Reynolds } \\
\text { men [34] } 2008\end{array}$ & USA & $\begin{array}{l}\text { Physician health } \\
\text { study trial subjects }\end{array}$ & $\begin{array}{l}\text { Age, smoking, Self-reported BP, TC, } \\
\text { HDL, diabetics excluded in baseline, } \\
\text { family history, hs-CRP }\end{array}$ & $\begin{array}{l}\text { Deaths from CHD and other fatal CVD, } \\
\text { MI, stroke, revascularisation } \\
\text { interventions }\end{array}$ \\
\hline $\begin{array}{l}\text { Personal } \\
\text { heart [39] men } \\
2007\end{array}$ & USA & Population cohort & $\begin{array}{l}\text { Men age, smoking, previous diagnosis of } \\
\text { HTN, previous diagnosis of } \\
\text { hypercholesterolemia, previous diagnosis } \\
\text { of diabetes, family history, physical } \\
\text { activity } \\
\text { Women age, smoking, previous diagnosis } \\
\text { of hypertension, previous diagnosis of } \\
\text { hypercholesterolemia, previous diagnosis } \\
\text { of diabetes, BMI }\end{array}$ & $\begin{array}{l}\text { Death from CHD, MI, revascularisation } \\
\text { intervention }\end{array}$ \\
\hline $\begin{array}{l}\text { QRISK [31] } \\
2007\end{array}$ & UK & $\begin{array}{l}\text { Electronic medical } \\
\text { database }\end{array}$ & $\begin{array}{l}\text { Age, sex, smoking, SBP, TC: HDL, } \\
\text { diabetics excluded in baseline, } \\
\text { antihypertensives, BMI, family history, } \\
\text { townsend }\end{array}$ & $\begin{array}{l}\text { Deaths from CHD and other fatal CVD, } \\
\text { MI, stroke, TIA, angina pectoris }\end{array}$ \\
\hline $\begin{array}{l}\text { QRISK2 [32] } \\
2008\end{array}$ & UK & $\begin{array}{l}\text { Electronic medical } \\
\text { database }\end{array}$ & $\begin{array}{l}\text { Age, sex, smoking, SBP, TC: HDL, } \\
\text { FBS, antihypertensive, BMI, ethnic- } \\
\text { ity, family history, townsend, } \\
\text { rheumatoid arthritis, chronic renal } \\
\text { disease, atrial fibrillation }\end{array}$ & $\begin{array}{l}\text { Deaths from CHD and other fatal CVD, } \\
\text { MI, ischaemic stroke, TIA, angina } \\
\text { pectoris }\end{array}$ \\
\hline $\begin{array}{l}\text { NHEFS [2] } \\
2008\end{array}$ & USA & Population cohort & $\begin{array}{l}\text { Age, sex, smoking, SBP, previous } \\
\text { diagnosis of diabetes, BMI }\end{array}$ & $\begin{array}{l}\text { Deaths from CHD and other fatal CVD, } \\
\text { MI, stroke, revascularisation } \\
\text { interventions, Hypertensive CCF }\end{array}$ \\
\hline $\begin{array}{l}\text { IHMRS [41] } \\
2011\end{array}$ & 52 countries & $\begin{array}{l}\text { Cases of MI, age } \\
\text { ( } \pm 5 \text { years), and } \\
\text { sex-matched } \\
\text { controls }\end{array}$ & $\begin{array}{l}\text { Age, apolipoprotein } \mathrm{B}: \mathrm{A} 1 \\
\text { ratio, smoking, second-hand smoke, } \\
\text { diabetes, high blood pressure }\end{array}$ & Cases of acute MI \\
\hline
\end{tabular}

SBP: systolic blood pressure, TC: Total cholesterol, HDL: High density lipoproetein, LDL: low density lipoprotein, TG: triglyceride FBS: Fasting blood sugar, HR: Heart rate MI: myocardial infarct, TIA: transient ischemic attack, PAD: peripheral artery disease, CCF: congestive cardiac failure.

by underestimating lifetime risk among South Asians. To overcome this underestimation, the recent UK lipid-lowering guidelines suggest that absolute risk estimated with an earlier version of the Framingham CVD score should be multiplied by 1.4 for men of South Asian origin [46]. However, this multiplication has the possibility of incorrect adjustments as South Asians possess a number of heterogeneous CVD risk factors as already discussed.

Although the classical CVD risk factors such as age, smoking, dyslipidaemia, elevated blood pressure, and abnormal glucose metabolism apply to South Asians as they do to Caucasians, Chinese and African populations, the British Cardiac Society among others has warned against assuming that risk scoring methods developed in non-South Asian populations can be directly applied to South Asians [46]. This is partly because data regarding incident CVD mortality and morbidity and risk factor prevalence are inadequate for most South Asian populations, therefore not allowing calibration of a CVD risk score derived from another population. Moreover, there was no local longitudinal cohort to supply robust information on the relation between CVD risk factors and outcomes. As a result, the extent to which the "classical" risk factors actually explain the rates of CVD among South Asians is still largely unanswered.
4.1. Chronological Age and CVD Risk. Although chronological age partly influences the formation of atherosclerotic plaque, it does not reflect true cardiovascular age [47]. As a result, assigning the same CVD risks to all individuals of the same chronologic age will be problematic because of the great variation in plaque burden at that point in a lifetime [47]. Yet, age remains one of the key variables in CVD risk scores. The sensitivity of the Framingham risk score and SCORE was lower in the younger age group (40-45 years) and older age group (70-85 years) compared with that in the middle age group (55-64 years) [48] even when risk factor levels were unfavourable among the younger persons. For example, the Framingham score nearly reached $10 \%$ risk in people aged 18-29 years and calculated risk $<12 \%$ in people aged 30-39 years despite the fact that the risk factor burden was remarkably high in these young individuals. In the INTERHEART study, hypertension, smoking, dyslipidaemia, and diabetes in women $<60$ years of age were more strongly associated with myocardial infarction than the presence of the same risk factors in women $>60$ years of age [13]. A concerning fact for South Asians is that CVD risk for this group should be estimated at least 10 years earlier than in Caucasians and Chinese as these people harbinger CVD risk factors at a younger age $[7,13]$. Additionally, there may be 
variations in the extent of atherosclerosis due to not only "conventional" but also novel risk factors which can partly explain their higher rates of CVD [8].

4.2. Migration and Changes in CVD Risk Factors. Migration is associated with changes in lifestyle, psychosocial interaction, dietary habit, climate, culture, and living conditions, which ultimately may influence the CVD risk profile. However, the change in CVD risk depends on the country which migration has taken place from and the country to which people have migrated. Most studies have reported that migration has a deleterious effect on CVD risk factors. For example, migrants from the Indian subcontinent who settled in the USA, UK, or other European countries have been reported to have increased obesity, apolipoprotein B levels [7, 11, 49], fasting plasma insulin [11, 49], C-reactive protein [49], serum triglyceride [50], and decreased $\beta$ cell functions [11, 49] compared to the natives of those countries [11, 49-51]. In addition, migration could be associated with significant psychosocial stress that may impact on CVD, though such evidence is sparse [52]. All these factors make it questionable whether the risk score derived from the Strong Heart study (undertaken in American Indians) or ARIC and UKPDS algorithms in which ethnicity is considered as one of the risk factors can be transferred directly for use in the South Asian populations.

4.3. Central Obesity and Insulin Resistance in South Asians. Several explanations including the role of body composition have been proposed to explain the paradox between the high prevalence of diabetes and atherosclerotic CVD despite a lower mean BMI and waist circumference among South Asians. Studies have shown that for a given BMI or waist circumference South Asian males had approximately 6\% higher total body fat than Caucasian men [52]. Additionally, South Asians had larger abdominal subcutaneous adipocytes than Caucasians, a phenomenon associated with insulin resistance independent of waist circumference. Several longitudinal studies have demonstrated that individuals who are insulin resistant develop abnormal CVD risk factors long before the development of overt diabetes $[41,52]$. These abnormal CVD risk factors include low adiponectin and altered adipokines levels, lipid abnormalities [41], glucose intolerance, elevated blood pressure [41, 52], chronic inflammation [52], and an increased procoagulant state [41] that ultimately lead to microvascular and macrovascular complications [41, 52, 53]. Risk assessment is a useful tool in CVD prevention as it promotes the most effective and cost-effective use of preventive strategies and highlights the importance of lifestyle modification. It may also be used as a motivational tool according to the manner in which it is presented. South Asian populations are well known to suffer an excessive and premature burden of CVD. But, estimating their CVD risk accurately is difficult as the popular risk algorithms either underestimate [12] or overestimate the CVD risk [42], and different algorithms often predict CVD risk differently in the same individual [12].
4.4. Strengths and Limitations. This review is a qualitative synthesis of published studies which used different epidemiological designs with varying sample sizes and did not adhere only to the hierarchy of evidence. However, the literature search was systematic, and the qualitative synthesis that was made was robust. Moreover, this study provides complete information on prevailing CVD risk factors and the vulnerability of the South Asians to CVD, the CVD risk factors difference between South Asians and Caucasians and others, and the risk factors included in the currently available risk scores and their prediction of CVD risk among these populations.

\section{Conclusion}

For South Asians, the risk scoring method should include a range of variables that provide an accurate estimate of risk within complex population structures with differences in sociodemographic groups, comorbidities, culture, environmental features, linguistics, and population dynamics. Final challenges include how to assess risk in younger individuals and how to better individualise risk rather than to stratify risk within subgroups of the adult population. This is now being assessed by the extent to which new risk factors/markers appropriately reclassify risk between those who do and do not develop CVD [54].

\section{Conflict of Interests}

The authors declare that they have no conflict of interests.

\section{References}

[1] A. D. Alwan, G. Galea, and D. Stuckler, "Development at risk: Addressing noncommunicable diseases at the United Nations high-level meeting," Bulletin of the World Health Organization, vol. 89, no. 8, pp. 546-546, 2011.

[2] T. A. Gaziano, C. R. Young, G. Fitzmaurice, S. Atwood, and J. M. Gaziano, "Laboratory-based versus non-laboratory-based method for assessment of cardiovascular disease risk: the NHANES I Follow-up Study cohort," The Lancet, vol. 371, no. 9616, pp. 923-931, 2008.

[3] R. S. Vasan and W. B. Kannel, "Strategies for cardiovascular risk assessment and prevention over the life course: progress amid imperfections," Circulation, vol. 120, no. 5, pp. 360-363, 2009.

[4] The World Bank, "South Asia Regional Brief. The World Bank Group," http://www.worldbank.org/en/news/2012/09/25/southAsia-Regional-Brief, 2012.

[5] F. P. Cappuccio, D. G. Cook, R. W. Atkinson, and P. Strazzullo, "Prevalence, detection, and management of cardiovascular risk factors in different ethnic groups in South London," Heart, vol. 78, no. 6, pp. 555-563, 1997.

[6] R. Bhopal, N. Unwin, M. White et al., "Heterogeneity of coronary heart disease risk factors in Indian, Pakistani, Bangladeshi, and European origin populations: cross sectional study," British Medical Journal, vol. 319, no. 7204, pp. 215-220, 1999.

[7] P. Joshi, S. Islam, P. Pais et al., "Risk factors for early myocardial infarction in South Asians compared with individuals in other 
countries," Journal of the American Medical Association, vol. 297, no. 3, pp. 286-294, 2007.

[8] S. S. Anand, S. Yusuf, V. Vuksan et al., "Differences in risk factors, atherosclerosis, and cardiovascular disease between ethnic groups in Canada: The Study of Health Assessment and Risk in Ethnic groups (SHARE)," The Lancet, vol. 356, no. 9226, pp. 279-284, 2000.

[9] J. C. Chambers, S. Eda, P. Bassett et al., "C-reactive protein, insulin resistance, central obesity, and coronary heart disease risk in Indian Asians from the United Kingdom compared with European whites," Circulation, vol. 104, no. 2, pp. 145-150, 2001.

[10] M. Chiu, P. C. Austin, D. G. Manuel, and J. V. Tu, "Comparison of cardiovascular risk profiles among ethnic groups using population health surveys between 1996 and 2007," CMAJ, vol. 182, no. 8, pp. E301-E310, 2010.

[11] D. Bhatnagar, I. S. Anand, P. N. Durrington et al., "Coronary risk factors in people from the Indian subcontinent living in West London and their siblings in India," The Lancet, vol. 345, no. 8947, pp. 405-409, 1995.

[12] S. Kanjilal, V. S. Rao, M. Mukherjee et al., "Application of cardiovascular disease risk prediction models and the relevance of novel biomarkers to risk stratification in Asian Indians," Vascular Health and Risk Management, vol. 4, no. 1, pp. 199-211, 2008.

[13] P. S. Yusuf, S. Hawken, S. Ônpuu et al., "Effect of potentially modifiable risk factors associated with myocardial infarction in 52 countries (the INTERHEART study): case-control study," The Lancet, vol. 364, no. 9438, pp. 937-952, 2004.

[14] D. Mahajan and M. A. Bermingham, "Risk factors for coronary heart disease in two similar Indian population groups, one residing in India, and the other in Sydney, Australia," European Journal of Clinical Nutrition, vol. 58, no. 5, pp. 751-760, 2004.

[15] J. C. States, S. Srivastava, Y. Chen, and A. Barchowsky, "Arsenic and cardiovascular disease," Toxicological Sciences, vol. 107, no. 2, pp. 312-323, 2009.

[16] K. M. McCarty, H. T. Hanh, and K. Kim, "Arsenic geochemistry and human health in South East Asia," Reviews on Environmental Health, vol. 26, no. 1, pp. 71-78, 2011.

[17] S. M. I. Huq, J. C. Joardar, S. Parvin, R. Correll, and R. Naidu, "Arsenic contamination in food-chain: transfer of arsenic into food materials through groundwater irrigation," Journal of Health, Population and Nutrition, vol. 24, no. 3, pp. 305-316, 2006.

[18] S. Dasgupta, M. Huq, M. Khaliquzzaman, K. Pandey, and D. Wheeler, "Indoor air quality for poor families: new evidence from Bangladesh," Indoor Air, vol. 16, no. 6, pp. 426-444, 2006.

[19] K. Balakrishnan, P. Ramaswamy, S. Sambandam et al., "Air pollution from household solid fuel combustion in India: an overview of exposure and health related information to inform health research priorities," Global health action, vol. 4, 2011.

[20] United Nations Children's Fund and The World Health Organization, Low Birthweight: Country, Regional and Global Estimates, UNICEF, New York, NY, USA, 2004.

[21] T. Meas, "Fetal origins of insulin resistance and the metabolic syndrome: a key role for adipose tissue?" Diabetes and Metabolism, vol. 36, no. 1, pp. 11-20, 2010.

[22] K. K. Ong and D. B. Dunger, "Birth weight, infant growth and insulin resistance," European Journal of Endocrinology, Supplement, vol. 151, supplement 3, pp. U131-U139, 2004.
[23] D. J. P. Barker, P. D. Gluckman, K. M. Godfrey, J. E. Harding, J. A. Owens, and J. S. Robinson, "Fetal nutrition and cardiovascular disease in adult life," The Lancet, vol. 341, no. 8850, pp. 938-941, 1993.

[24] R. B. D’Agostino Sr., S. Grundy, L. M. Sullivan, and P. Wilson, "Validation of the Framingham coronary heart disease prediction scores: results of a multiple ethnic groups investigation," Journal of the American Medical Association, vol. 286, no. 2, pp. 180-187, 2001.

[25] D. M. Lloyd-Jones, E. P. Leip, M. G. Larson et al., "Prediction of lifetime risk for cardiovascular disease by risk factor burden at 50 years of age," Circulation, vol. 113, no. 6, pp. 791-798, 2006.

[26] W. B. Kannel, D. McGee, and T. Gordon, "A general cardiovascular risk profile: the Framingham study," American Journal of Cardiology, vol. 38, no. 1, pp. 46-51, 1976.

[27] K. M. Anderson, P. W. F. Wilson, P. M. Odell, and W. B. Kannel, "An updated coronary risk profile. A statement for health professionals," Circulation, vol. 83, no. 1, pp. 356-362, 1991.

[28] R. B. D’Agostino Sr., R. S. Vasan, M. J. Pencina et al., "General cardiovascular risk profile for use in primary care: the Framingham heart study," Circulation, vol. 117, no. 6, pp. 743-753, 2008.

[29] G. Assmann, H. Schulte, P. Cullen, and U. Seedorf, "Assessing risk of myocardial infarction and stroke: new data from the Prospective Cardiovascular Münster (PROCAM) study," European Journal of Clinical Investigation, vol. 37, no. 12, pp. 925-932, 2007.

[30] L. E. Chambless, A. R. Folsom, A. R. Sharrett et al., "Coronary heart disease risk prediction in the Atherosclerosis Risk in Communities (ARIC) study," Journal of Clinical Epidemiology, vol. 56, no. 9, pp. 880-890, 2003.

[31] J. Hippisley-Cox, C. Coupland, Y. Vinogradova, J. Robson, M. May, and P. Brindle, "Derivation and validation of QRISK, a new cardiovascular disease risk score for the United Kingdom: prospective open cohort study," British Medical Journal, vol. 335, no. 7611, pp. 136-141, 2007.

[32] J. Hippisley-Cox, C. Coupland, Y. Vinogradova et al., "Predicting cardiovascular risk in England and Wales: prospective derivation and validation of QRISK2," British Medical Journal, vol. 336, no. 7659, pp. 1475-1482, 2008.

[33] P. M. Ridker, J. E. Buring, N. Rifai, and N. R. Cook, "Development and validation of improved algorithms for the assessment of global cardiovascular risk in women: The Reynolds Risk Score," Journal of the American Medical Association, vol. 297, no. 6, pp. 611-619, 2007.

[34] P. M. Ridker, N. P. Paynter, N. Rifai, J. M. Gaziano, and N. R. Cook, "C-reactive protein and parental history improve global cardiovascular risk prediction: the Reynolds risk score for men," Circulation, vol. 118, no. 22, pp. 2243-2251, 2008.

[35] M. Woodward, P. Brindle, and H. Tunsfall-Pedoe, "Adding social deprivation and family history to cardiovascular risk assessment: The ASSIGN score from the Scottish Heart Health Extended Cohort (SHHEC)," Heart, vol. 93, no. 2, pp. 172-176, 2007.

[36] E. T. Lee, B. V. Howard, W. Wang et al., "Prediction of coronary heart disease in a population with high prevalence of diabetes and albuminuria: The Strong Heart Study," Circulation, vol. 113, no. 25, pp. 2897-2905, 2006.

[37] Y. Wu, X. Liu, X. Li et al., "Estimation of 10-year risk of fatal and nonfatal ischemic cardiovascular diseases in chinese adults," Circulation, vol. 114, no. 21, pp. 2217-2225, 2006. 
[38] R. M. Conroy, K. Pyörälä, A. P. Fitzgerald et al., "Estimation of ten-year risk of fatal cardiovascular disease in Europe: The SCORE project," European Heart Journal, vol. 24, no. 11, pp. 9871003, 2003.

[39] A. G. Mainous III, R. J. Koopman, V. A. Diaz, C. J. Everett, P. W. F. Wilson, and B. C. Tilley, "A coronary heart disease risk score based on patient-reported information," American Journal of Cardiology, vol. 99, no. 9, pp. 1236-1241, 2007.

[40] R. J. Stevens, V. Kothari, A. I. Adler, I. M. Stratton, and R. R. Holman, "The UKPDS risk engine: a model for the risk of coronary heart disease in type II diabetes (UKPDS 56)," Clinical Science, vol. 101, no. 6, pp. 671-679, 2001.

[41] C. McGorrian, S. Yusuf, S. Islam et al., "Estimating modifiable coronary heart disease risk in multiple regions of the world: The INTERHEART Modifiable Risk Score," European Heart Journal, vol. 32, no. 5, pp. 581-590, 2011.

[42] P. Jeemon, D. Prabhakaran, M. D. Huffman et al., "Distribution of 10-year and lifetime predicted risk for cardiovascular disease in the Indian Sentinel Surveillance Study population (crosssectional survey results)," British Medical Journal Open, vol. 1, no. 1, Article ID e000068, 2011.

[43] M. W. Cavanaugh-Hussey, J. D. Berry, and D. M. Lloyd-Jones, "Who exceeds ATP-III risk thresholds? Systematic examination of the effect of varying age and risk factor levels in the ATP-III risk assessment tool," Preventive Medicine, vol. 47, no. 6, pp. 619623, 2008.

[44] M. J. Pencina, R. B. D’Agostino, M. G. Larson, J. M. Massaro, and R. S. Vasan, "Predicting the 30-year risk of cardiovascular disease: the framingham heart study," Circulation, vol. 119, no. 24, pp. 3078-3084, 2009.

[45] P. M. Brindle, A. McConnachie, M. N. Upton, C. L. Hart, G. D. Smith, and G. C. M. Watt, "The accuracy of the Framingham risk-score in different socioeconomic groups: a prospective study," British Journal of General Practice, vol. 55, no. 520, pp. 838-845, 2005.

[46] A. Cooper and N. O’Flynn, “Guidelines. Risk assessment and lipid modification for primary and secondary prevention of cardiovascular disease: summary of NICE guidance," British Medical Journal, vol. 336, no. 7655, pp. 1246-1248, 2008.

[47] S. M. Grundy, "Coronary plaque as a replacement for age as a risk factor in global risk assessment," The American Journal of Cardiology, vol. 88, no. 2A, pp. 8E-11E, 2001.

[48] E. Ketola, T. Laatikainen, and E. Vartiainen, "Evaluating risk for cardiovascular diseases-vain or value? How do different cardiovascular risk scores act in real life," European Journal of Public Health, vol. 20, no. 1, pp. 107-112, 2010.

[49] J. V. Patel, A. Vyas, J. K. Cruickshank et al., "Impact of migration on coronary heart disease risk factors: comparison of Gujaratis in Britain and their contemporaries in villages of origin in India," Atherosclerosis, vol. 185, no. 2, pp. 297-306, 2006.

[50] S. U. B. Tennakoon, B. N. Kumar, D. B. Nugegoda, and H. E. Meyer, "Comparison of cardiovascular risk factors between Sri Lankans living in Kandy and Oslo," BMC Public Health, vol. 10, article 654, 2010.

[51] N. Zahid, H. E. Meyer, B. N. Kumar, B. Claussen, and A. Hussain :, "High levels of cardiovascular risk factors among Pakistanis in Norway compared to Pakistanis in Pakistan," Journal of Obesity, vol. 2011, Article ID 163749, 5 pages, 2011.

[52] F. B. Hu, M. J. Stampfer, S. M. Haffner, C. G. Solomon, W. C. Willett, and J. E. Manson, "Elevated risk of cardiovascular disease prior to clinical diagnosis of type 2 diabetes," Diabetes Care, vol. 25, no. 7, pp. 1129-1134, 2002.

[53] J. Nigro, N. Osman, A. M. Dart, and P. J. Little, "Insulin resistance and atherosclerosis," Endocrine Reviews, vol. 27, no. 3, pp. 242-259, 2006.

[54] M. J. Pencina, R. B. D’Agostino, and E. W. Steyerberg, "Extensions of net reclassification improvement calculations to measure usefulness of new biomarkers," Statistics in Medicine, vol. 30, no. 1, pp. 11-21, 2011.

[55] N. Brown, C. K. Sasidharan, and D. Fisher, "Early growth and markers of cardiovascular risk in Keralan children in the Integrated Child Development Scheme," Public Health Nutrition, vol. 13, no. 7, pp. 1042-1048, 2010.

[56] R. A. DeFronzo, "Insulin resistance, lipotoxicity, type 2 diabetes and atherosclerosis: the missing links. The Claude Bernard Lecture 2009," Diabetologia, vol. 53, no. 7, pp. 1270-1287, 2010.

[57] P. W. F. Wilson, R. B. D’Agostino, D. Levy, A. M. Belanger, H. Silbershatz, and W. B. Kannel, "Prediction of coronary heart disease using risk factor categories," Circulation, vol. 97, no. 18, pp. 1837-1847, 1998.

[58] L. A. Simons, J. Simons, Y. Friedlander, J. McCallum, and L. Palaniappan, "Risk functions for prediction of cardiovascular disease in elderly Australians: The Dubbo Study," Medical Journal of Australia, vol. 178, no. 3, pp. 113-116, 2003.

[59] L. Palmieri, S. Panico, D. Vanuzzo et al., "Evaluation of the global cardiovascular absolute risk: The Progetto CUORE individual score," Annali dell'Istituto Superiore di Sanita, vol. 40, no. 4, pp. 393-399, 2004.

[60] B. Balkau, "Prediction of the risk of cardiovascular mortality using a score that includes glucose as a risk factor. The DECODE Study," Diabetologia, vol. 47, no. 12, pp. 2118-2128, 2004.

[61] A. Menotti, M. Lanti, E. Agabiti-Rosei et al., "Riskard 2005. New tools for prediction of cardiovascular disease risk derived from Italian population studies," Nutrition, Metabolism and Cardiovascular Diseases, vol. 15, no. 6, pp. 426-440, 2005.

[62] X. Zhang, J. Attia, C. D'Este, X. Yu, and X. Wu, “A risk score predicted coronary heart disease and stroke in a Chinese cohort," Journal of Clinical Epidemiology, vol. 58, no. 9, pp. 951958, 2005.

[63] "Risk assessment chart for death from cardiovascular disease based on a 19-year follow-up study of a Japanese representative population," Circulation Journal, vol. 70, no. 10, pp. 1249-1255, 2006. 


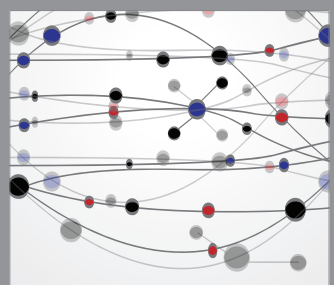

The Scientific World Journal
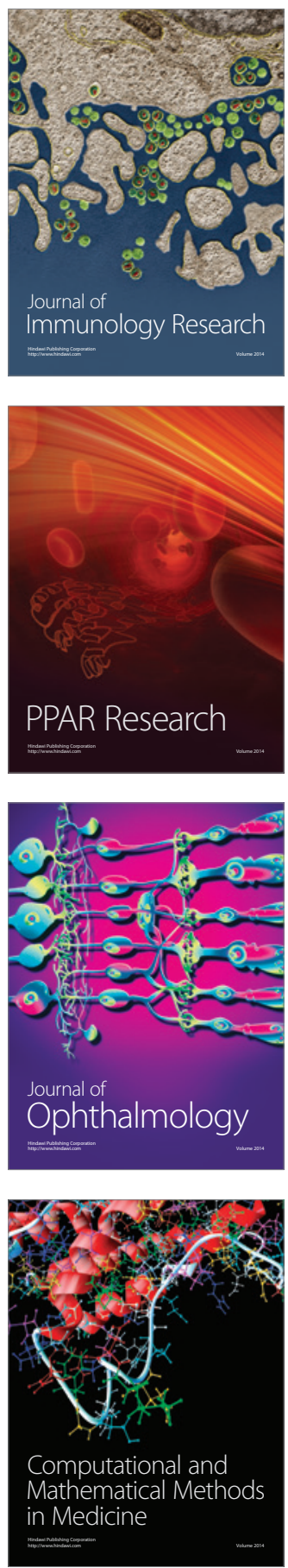

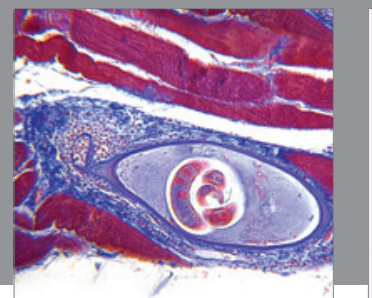

Gastroenterology

Research and Practice
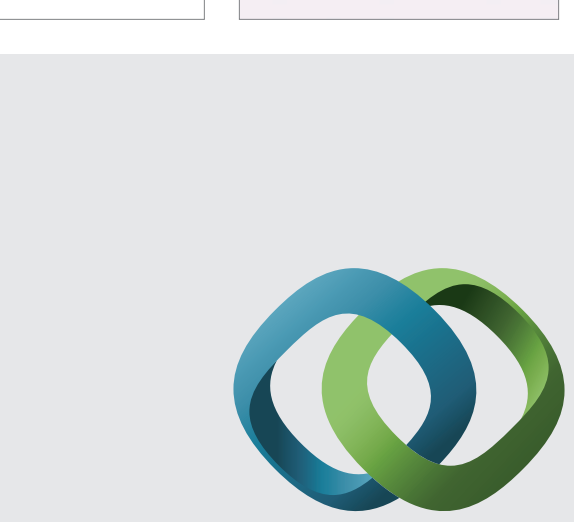

\section{Hindawi}

Submit your manuscripts at

http://www.hindawi.com
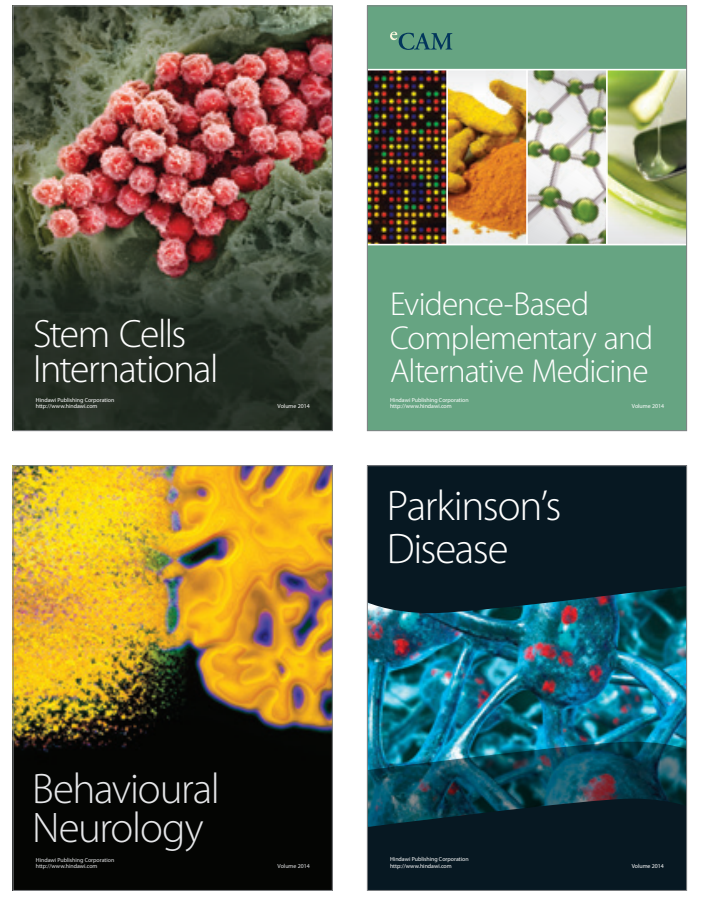
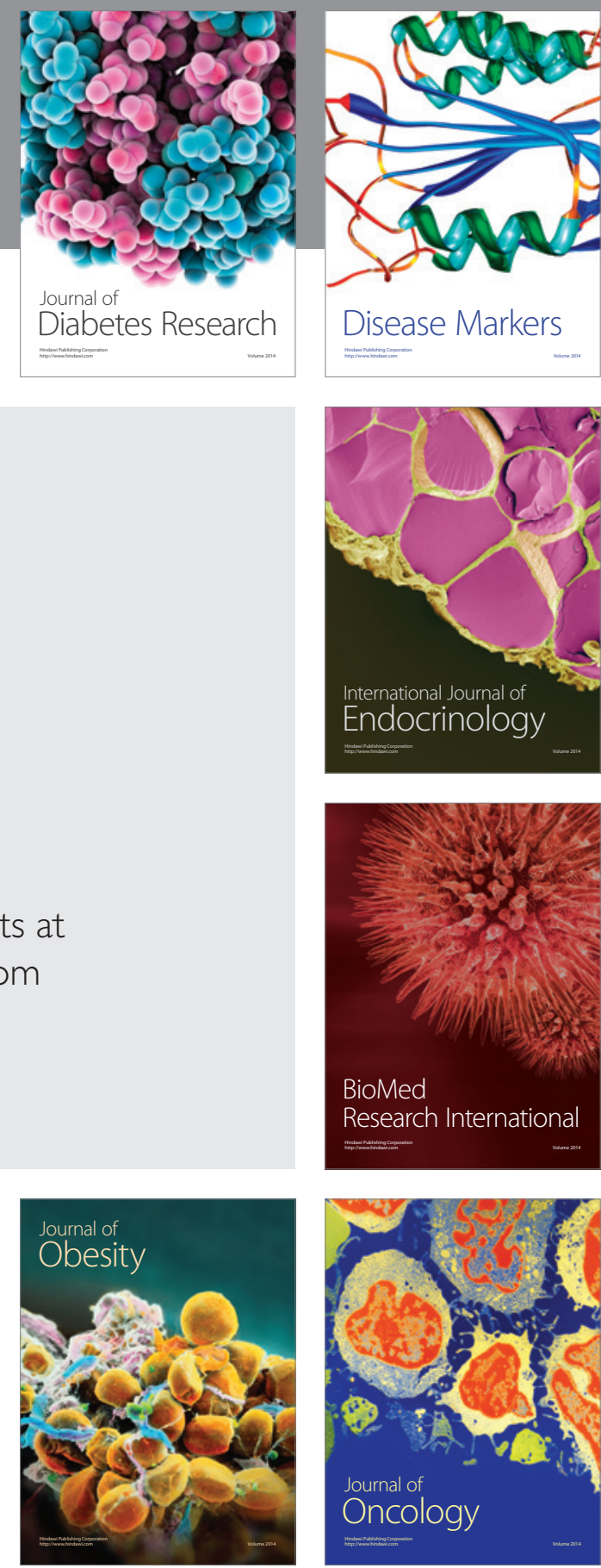

Disease Markers
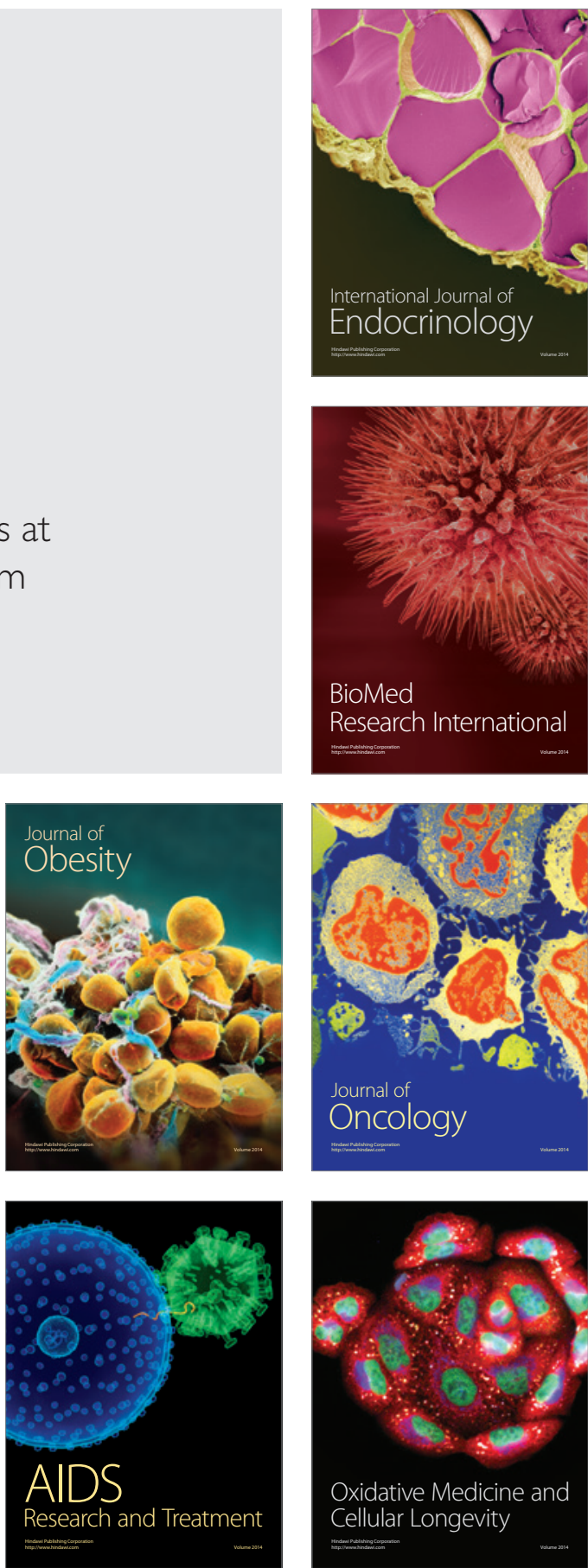